\title{
Implementation of Balanced Scorecard in Indonesian Government Institutions: A Systematic Literature Review
}

\author{
I Gede Ari Erawan* \\ *Indonesian Ministry of Finance Indonesia
}

\section{ARTICLE INFORMATION}

\section{Article history:}

Data submission : August 20, 2019

$1^{\text {st }}$ revision: September 21, 2019

Accepted: November 12, 2019

Available online: December 12, 2019

Keywords: balanced scorecard, Government Institution, Performance Accountability, bureaucratic reform, good governance

\begin{abstract}
In order to meet public pressure in improving government performance, many government institutions practice balanced scorecard as their performance management system. This paper describes how Indonesian government institutions implement balanced scorecard and its contribution toward their performance accountability. Delivering a systematic literature review of publications related to the implementation of balanced scorecard in public sector, it can be inferred that balanced scorecard helps the manager in Indonesian Ministry of Finance to fill the gap between strategic planning and strategic outcomes. Although, it has own disadvantages, balanced scorecard has proven on enhancing institution performance accountability based on evaluation conducted by Ministry of State Apparatus and Bureaucratic Reform. Its contribution is largely in performance planning indicator, since balanced scorecard focuses on strategic planning. Not only improves performance accountability, it is also founded that balanced scorecard supports the improvement of bureaucratic reform index. The essential factors in developing balanced scorecard implementation are explained as well. However, the differences compared to non-balanced scorecard organizations, has not been studied due to the limitation of the data, therefore future research is suggested.
\end{abstract}

2019 FIA UB. All rights reserved.

\section{Introduction}

Nowadays, public awareness in the government accountability is increasing. Public, as tax payers, became more critical in perceiving the performance of public institution. Indonesian government institutions have to report their performance accountability every year as stated in The Presidential Decree No 29 of 2014 on Performance Accountability System of Government Institution. This report describes how the government institution manage their performance, for instance how they plan their strategic objectives based on their vision and missions, how they define their workplan and how their performance is measured. Not only for measuring performance, performance accountability also can be an indicator of bureaucratic reform, therefore eventually can enhance good governance in a government institution.
Every government institution has to provide this information to public as their main stakeholder. In addition, public can evaluate, how well government institutions spend state budget to do their mandates and public expectation is high. Therefore, our public institutions have to develop, aligning with the expectation of public itself.

Thus, several government institutions tried to implement balanced scorecard as a breakthrough method to create better performance institutions. Research about the implementation of balanced scorecard in public sector in developed countries is well-maintained, however, it is quite rare to find research about this particular topic in Indonesia, specifically the research, that studies correlation between implementation of balanced scorecard toward the performance accountability system. This paper hopefully can give an insight whether

\footnotetext{
*Corresponding author email: gedheirawan@gmail.com
} 
balanced scorecard do contribute to the improvement of performance accountability in Indonesian government institution. Working in an Indonesian Ministry of Finance, that has performed balanced scorecard for a decade, encourage the author to thoroughly studying the implementation of balanced scorecard, moreover can positively contribute in improving balanced scorecard system in Indonesian public institutions.

\section{Discussion}

\subsection{The establishment of balanced scorecard}

Introduced by Robert S. Kaplan and David P. Norton in Harvard Business Review in 1992, balanced scorecard is a new concept for the managers to do a quick and comprehensive review of their businesses (Kaplan \& Norton, 1992). At that time, many institutions used traditional financial measures to examine all aspects of business such as competencies of human resources and innovations. This, however, can result unreliable data and will complicate the managers to plan strategic objectives in order to improve institution performance. balanced scorecard tackles this issue by adding another measurement, that be able to comprehensively and simultaneously measure all the business criteria. Balanced scorecard came as many managers want the balanced presentation of both financial and operational measures (Kaplan \& Norton, 1992). balanced scorecard allows more specific perspectives to evaluate an aspect that is critical for institution continuous improvement, human resources, for instance. Adding more perspectives does not mean adding much information, nonetheless balanced scorecard focuses on particular perspectives by creating certain measurements thus it can give the managers important information in decision-making process.

Kaplan and Norton (1992) in their article "The balanced scorecard- Measures that Drive Performance" formulates four perspectives to help the managers evaluate business performance:

\subsubsection{Customer perspective}

This perspective measures how companies deliver its value to its customers. This perspective translate customer needs i.e. time, quality, and performance and service into specific measures. For instance, a company performs customer satisfaction surveys to its customer in order to know what customer perception toward company services. Based on the survey's results, a company can evaluate the services that can be improved. This particular perspective is considered the significant one, because customer satisfaction is a main objective for sustainable business process.

\subsubsection{Internal business perspective}

This perspective answers the question how to improve customers satisfaction, it has to be started from internal business process. Managers have to strategically plan a comprehensive business process to improve business performance, that includes the synergy of all employees and the use of information technology system. To illustrate, refers to the result of customer satisfaction surveys, it can be concluded that the customers want faster delivery services, therefore the managers evaluate the business process to meet the customer expectancies

\subsubsection{Innovation and learning perspective}

Sometimes managers ignore this perspective, they do not want to invest on creating innovation and increasing human resources skill because it will cost a large amount of money. Nevertheless, in order to survive in this more competitive market, companies should bring distinguished values to their customers. It can be achieved by continuous learning process. Amazon, for instance, one of a leader in e-commerce, has used drones to deliver its product to its customers. This will, eventually, give a new experience for customers in receiving products. Continuous learning and innovation need serious commitment from managers due to its long process and time.

\subsubsection{Financial perspective}

This perspective examines all the actions that are done in other three perspectives, whether positively or negatively contribute to the fundamental financial objectives, e.g. profitability or return on investment (ROI). In some cases, improvement in process business does not directly correlate with improvement in financial perspective. For example, a company has improved its service delivery, however, its competitor has done better with their services, consequently, the managers will not gain financial benefit, because they lose to their competitor.

Furthermore, a manager should view all these perspectives as one big picture, that has causal relationship between each measure. From previous example, if a company loses to its competitor, the manager should put more attention in innovation and learning perspective. Moreover, each measure will be translated into Key Performance Indicator (KPI) to focus on actions that need to be done.

To make managers more focus on the actions, that can achieve these perspectives, it should be derived into strategic objectives. In Kaplan's another article, "Conceptual Foundation of balanced scorecard", he introduced strategy maps concept. This elaborates casual relation between strategic objectives which are grouped based on perspectives. Kaplan (1999) argues that the poorest relationship in strategic map is innovation and learning perspective and described it as "the black hole of 
balanced scorecard", because it is challenging to suitably link employee capabilities to the strategy objectives.

In order to properly implement balanced scorecard, it needs synergy from upper level managers to basic employees. However, the success of balanced scorecard implementation fully depends on the leadership of the managers. These are five leadership and management systems to establish the strategy-focused organization (SFO) according to Kaplan and Norton (1999): encourage change through executive leadership, interpret the strategy, derived strategy from the organization, inspire employees to combine strategy into their daily task, and impose strategy as a sustainable process.

\subsection{The benefit of balanced scorecard}

Based on study by Quesado et al. (2018), titled "Advantages and Contributions in the balanced scorecard Implementation", the advantages of balanced scorecard implementation can be viewed in two levels:

2.2.1. Benefits at the organization strategy level

- Entire organization function contributes to the achievement of strategic objectives through the establishment of indicators, goals, initiatives and personal alignment;

- Cascading process shows the synergies and commitment of the various employees, focusing on decision making on pursuing the business strategy;

- Simplify the complexity of management and decision process by making prioritized objectives, initiatives and motivating internal learning;

\subsubsection{Benefits at the strategic adjustment level}

- It allows tangible link of the mission and the organizational strategy;

- It brings in all levels of the organization in achieving common objectives and encouraging a spirit of cooperation;

- It helps to improve communication and visibility between senior executive and lower level employee

In addition, balanced scorecard helps the managers in decision making process by enabling the integration of internal and external measures and providing the availability of better data (Quesado et al., 2018).

One of the most notable success stories of balanced scorecard implementation is Mobil USM\&R. balanced scorecard has helped the manager to focus on fixing the weakness and improving the strength of current business process. Balanced scorecard also encourages the manager to decide their priorities based on the measurement of four perspectives (Kaplan, 1999).

\subsection{The flaws of balanced scorecard}

Despite its beneficial features, balanced scorecard has its imperfection. balanced scorecard demands appropriate strategic planning in order it can effectively contribute to company performance. Formulating strategic planning is not an easy task for the manager, it must engage all business stakeholders and employee. This strategic planning, furthermore, will be integrated within balanced scorecard perspectives. However, based on research in Australia, most managers do not pay aware attention to these aspects when draft their balanced scorecard (Ndevu \& Muller, 2018).

Another balanced scorecard limitation both in concept and practice as suggested by Awadallah and Alam (2015) in "A Critique of the balanced scorecard as a Performance Measurement tool" include:

- The concept of balanced scorecard does not have explicit relationship with organization performance;

- The goals and definition of measures do not include key stakeholder;

- Lack the definition of key success factors in order to identify key performance indicators;

- The four perspectives limit the restrict the view of organization;

- Focus on achieving its target can lead a company not to maximize its capability to achieve beyond its target;

- Recognize an organization as a hierarchical structure;

- Promote limited innovation.

Many organizations applied balanced scorecard with several changes to suit their organization characteristics. For instance, manufacture organizations tend to focus on customer perspective and internal business process. While, IT organizations consider innovation and learning perspective as their significant measure.

\subsection{Balanced scorecard approach in public sector}

Success stories from balanced scorecard implementation in private sector influenced governments to perform balanced scorecard in their institutions, as an attempt to enhance their services to public. Because public sector is not profit-oriented, not like private sector, therefore there will be several adjustments in its implementation. The most important differences are in identifying customer perspective and financial perspective.

Based on successful balanced scorecard implementation in the City of Charlotte, United States, it can be learned that the government imposed customer perspective at the top of scorecard. This describes insightful relationship between the government mission (providing public welfare) and the function of a local government. In addition, financial perspective in public sector is the main resource to deliver the public needs. The public needs should be provided both with best services and wisely use of government budget (Quesado et al. 2018). Financial and customer perspective can 
be integrated to perform framework in three level themes (Kaplan, 1999): (1). Cost incurred. This perspective stresses the significance of operational efficiency; (2). Value created. This subject identified how the public institution benefits the citizen. A subject that will be the most difficult to measure; (3). Legitimizing support. An important "customer" for any government institution will be its tax payers. Kaplan (1999) stated that "government institution must fulfill these levels to achieve its fundamental objectives, which are creating value at minimal cost and developing ongoing support".

Based on study by Pasaribu et al. (2016) in "A Review of Performance Management Using the balanced scorecard in Public Sector", it can be inferred $40 \%$ of 15 reviewed public institutions using financial perspective as the highest outcome. The reason many of these public institutions examine financial perspective as its fundamental objective, in other words, they still applied balanced scorecard approach in private institutions. Moreover, another $40 \%$ of the reviewed institutions were already implementing customer perspective as their highest outcome. Still in same study, many reviewed public institutions considered learning and growth perspective as the most significant perspective due to its function to increase the competency of the employees.

\subsection{The balanced scorecard Implementation in} Indonesian Government Institution

During the bureaucratic reform in Indonesian government organization, the government tried to improve their good governance by enhancing their management system. They tried to change the old paradigm of Indonesian public institutions, from slow services, unsatisfactory performance accountability, poor competency of civil servants, and regularly corruption practices to better quality services, good governance, IT integrated process and increasing the competency and integrity of civil servants. The most prominent performance management system, that has been adopted by several Indonesian government institution is balanced scorecard.

One success story of balanced scorecard implementation in Indonesian Government is the implementation in Indonesian Ministry of Finance (MoF). MoF has performed balanced scorecard as its performance measure tool since 2008. Why balanced scorecard, because $62 \%$ of reviewed organizations have adopted balanced scorecard (Lawson et al., 2008). At first, the implementation did not comprehensively measure all structures, only at top level (minister and echelon I officials). Furthermore, it has progressively developed, now, balanced scorecard is applied from top executive structures to lower level employees. The implementation has been supported by the development of its regulation from Minister of Finance decree no 87 of
2009 to newest Minister of Finance decree no 556 of 2015.

These are the balanced scorecard functions to support institution continuous improvement:

2.5.1. Balanced scorecard as a strategy execution tool

$\mathrm{MoF}$ uses balanced scorecard to fill the gap between strategic planning and strategic outcomes, which are 1) satisfied stakeholders, 2) delighted customers, 3) efficient and effective processes, 4) motivated and prepared human resources (SMO MoF, 2015). Balanced scorecard translates strategy planning into key performance indicators (KPIs) that are specific, measurable, approved, realistic, time-bounded and continuouslyimproved (SMART-C).

There are six levels of this implementation based on MoF hierarchy, from highest to lowest level, Kemenkeu-wide (minister and vice minister), Kemenkeu-one (echelon I officials), Kemenkeutwo (echelon II officials), Kemenkeu-three (echelon III officials), Kemenkeu-four (echelon IV officials) and Kemenkeu-five (expert staff, echelon $\mathrm{V}$ officials, and other employees). Communicating the top level and structural scorecards throughout the organization encourages each employee to align their daily tasks with the organization strategic outcomes (Kaplan, 1999).

The process is started by formulating a strategy map in Kemenkeu-wide level. Derived from the MoF vision and missions, Strategic map consists of four perspectives and each perspective contains strategic objectives. The main difference from balanced scorecard in private sector is in Mof, the managers change financial perspective with stakeholder perspective. Furthermore, they put stakeholder perspective at the highest position, followed by customer perspective, it is because MoF sets it objectives based on stakeholder expectation (SMO MoF, 2015). It is a different approach from the implementation in City of Charlotte, that set customer perspective as the highest perspective. The definition of stakeholders is anyone who influence or is influenced by an organizational action or products, while customer is anyone whom the organization is trying to satisfy through creating or updating the product (Mcdonald, 2018). MoF identifies stakeholder perspective i.e. President, House of Representatives, Supreme Audit Institution, citizens and bondholders, moreover, customers are tax payers, service user, entrepreneur, other ministries/government institution, and local government (MoF Strategy Map, 2019).

Despite the absence of financial perspective, the managers set its measurement in one of objectives in learning and growth perspective. If 
we compare the strategy map between Mof to Supreme Audit Institution (SAI), which has similar experience in implementing balanced scorecard, its strategy map consists of complete four perspective i.e. stakeholder perspective, internal process perspective, learning and growth perspective and financial perspective.

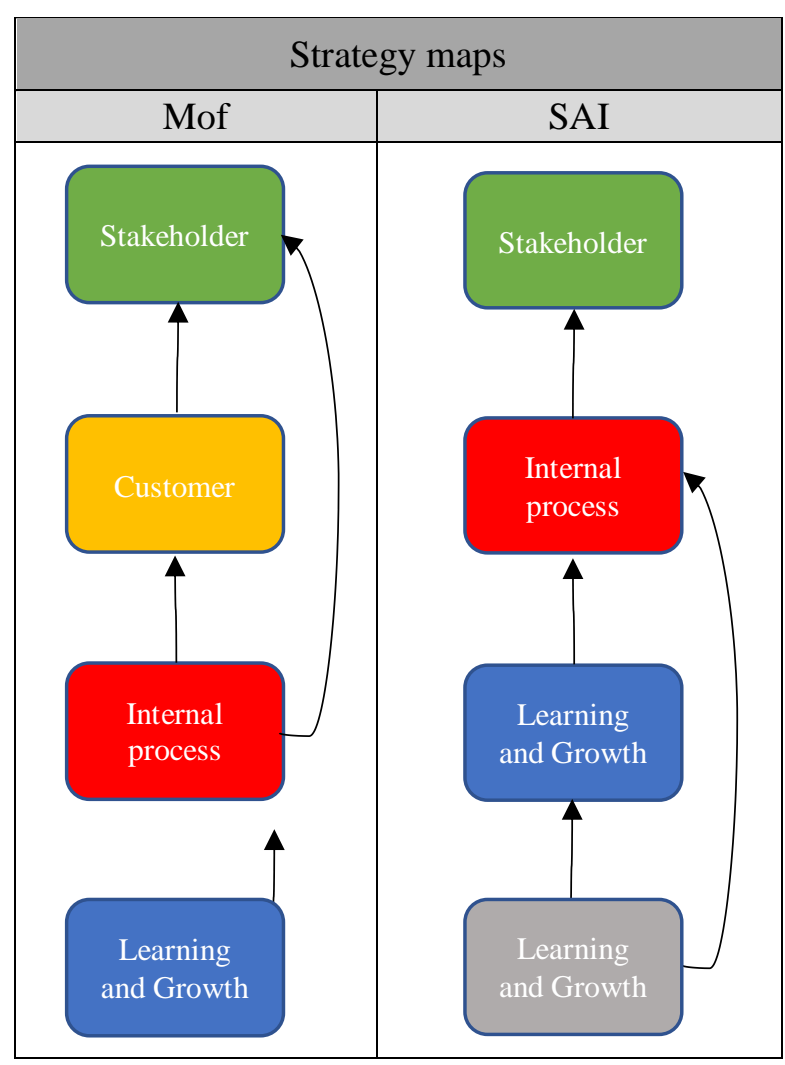

Source: MoF Strategy Map 2019 and SAI Performance accountability report 2018

Figure 1. The differences between strategy maps

Moreover, both financial perspective in SAI and financial measurement in MoF, measure how effective and efficient the organizations spend its budget to achieve its outcomes. After establishing a strategy map, It is devised into strategic objectives, further, KPIs are formed based on strategic objectives. The managers must consider the SMART-C in identifying KPIs' targets. The strategy map and KPIs in Kemenkeu-wide will be cascaded into strategy map and KPIs in Kemenkeutwo level and so on, until every employee has their own KPIs. The cascading process should consider the quality of KPIs based on structural characteristics and functions.

\subsubsection{Balanced scorecard as a measurement tool}

The managers quarterly evaluate their KPIs' targets achievement, and at the end of the year, they measure its achievement through comparing the realization to the target and reviewing the KPIs quality. As regulated in the Minister of Finance decree no 467 of 2014, the indicators of achievement are divided into three colors a) green, between 120 and 100 (have met the expectation); b) yellow, between 99 and 80 (have not met the expectation) and c) red, below 80 (do not meet the expectation).

In MoF, the evaluation and monitoring of performance achievement are done by conducting a performance dialogue. A performance dialogue is a strategy review meeting that is involved entire responsible entities from executive managers to lower employee. The purpose of this meeting are to rectify internal coordination and to make a decision that has strategic effect toward organizational performance and organizational culture. There are five principles in conducting a performance dialogue : a) factual based, decision making based on credible facts and easy to understand; b) action oriented, focus on action plans and all participants have to show full commitment; c) constructive and challenging, all participants have to give positive and progressive feedback; and d) targeted, creating solutions for the problems (Pasaribu et al. 2016).

2.5.3. Balanced scorecard as a performance accountability report

Based on Presidential Decree no 29 of 2014 on Performance Accountability System of Government Institutions, every government institution has to annually report and publish their performance management in order to achieve a good governance. MoF has integrated balanced scorecard into their performance accountability report, from planning, implementing to evaluation. According to Minister for State Apparatus Reform Decree no 53 of 2014, the purpose of performance reporting are to give measurable performance information to the stakeholders and to carry out continuous improvement for the government agencies.

Combining balanced scorecard has shown an enhancement in the quality of performance measurement in the performance reporting. It is proved by the result of performance accountability evaluation, conducted by Ministry for State Apparatus Reform. In 2016, MoF and SAI earned score of 83,79 and 80,45 , respectively which is considered satisfying ("A") among 77 other ministries and government agencies. Specifically, MoF achieved the highest score. (Ini Rapor Akuntabilitas Kinerja 77 Lembaga yang Dinilai Kemenpan $R B$, 2016). This evaluation assesses five components, 1) performance planning; 2) performance measurement; 3) performance reporting; 4) performance evaluation; and 5) 
performance achievement. In performance evaluation component, which were 8,14 and 8,70, respectively. In general, MoF scores have gradually increased from 80, 69 in 2014 to 87,07 in 2017. emphasizes on strategic planning. On the other hand, both in 2017 and 2018, the lowest result was in MoF. The bureaucratic reform index is an assessment to acquire information about the progress of bureaucratic reform (Minister for State Apparatus Reform Decree no 14 of 2014). Two of the indicators of this assessment are the strengthening of performance accountability and

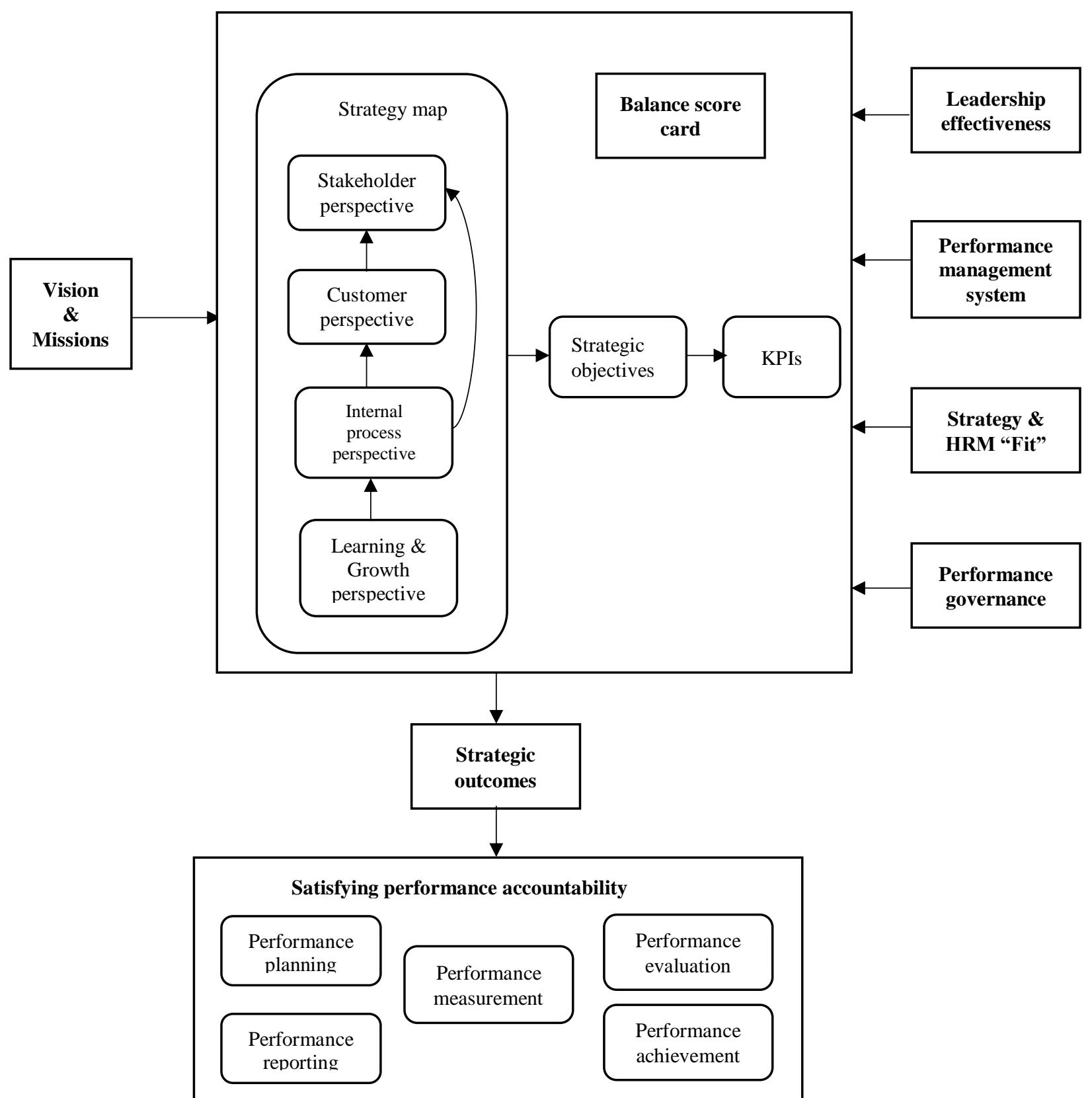

Figure 2. Framework on the implementation of balanced scorecard in $\mathrm{MoF}$

Balanced scorecard also positively supports the improvement of the bureaucratic reform index. Furthermore, both in 2017 and 2018, MoF earned the highest result in performance planning component $(25,46$ and 26,20 , respectively). This is due to balanced scorecard implementation, that result of the performance accountability evaluation.

2.5.4. The challenges in balanced scorecard implementation

In spite of its advantages, there are still challenges to continuously maintain or improve the implementation of balanced scorecard in government institutions. The hindrances can be within the organization such as unwillingly to 
report "bad news" and insufficiency of proper data (da Cruz \& Marques, 2014)

Based on study by Budiarso (2014), there are four fundamental characteristics that challenge the contribution of balanced scorecard toward the performance outcomes in MoF: (a) The organization characteristic e.g. inflexible structure, silo bureaucrats' mentality, and indecent punishment for incompetent employee; (b) Poor quality of human resource management in recruitment, training, promotion and remuneration; (c) Patronage, conservative organizational culture and mindset; (d) Lack of role model in leadership for encouraging performance governance.

To tackle these problems, several elements are necessity such as a supporting leadership, a transformation alignment and collaborative decision making (Ndevu \& Muller, 2018). Moreover, factors that contribute to the favorable outcome in balanced scorecard implementation can be divided into four factors (Budiarso, 2014): (a). Leadership effectiveness are the vital determinants of the successful of balanced scorecard implementation. The leaders, supported by KPI managers, must have the right vision and missions as the first stage of balanced scorecard implementation, encouraging all employees with motivation, steering the strategic and cultural change in the organization, guiding best employee as role models and working together as a team; (b). Performance management system, which includes issuing internal regulations to secure balanced scorecard as the MoF performance management system. Thus, internal regulations become legal instrument for integrating balanced scorecard through all structures in MoF; (c). Strategy and human resource management "Fit" recognize KPI managers' functions such as 1) to supervise the external environments and examine their effect on the organizational strategy; 2) to assist leaders in reviewing and improving a prevailing vision, missions and strategies; 3 ) to held a collaborative work with all units in order to establish comprehensive objectives and performance alignments among the units; and 4) to prepare periodic performance report; (d) Performance governance, that involves the good relationship with stakeholder and meets the public demand through bureaucratic reform.

\section{Conclusion}

Indonesian $\mathrm{MoF}$ has implemented balanced scorecard for a decade and it helps MoF to link its strategic planning to its strategic outcomes. Some adjustments have been done, in order to suit balanced scorecard to the characteristics of the organization. The significant one is the change from financial perspective to stakeholder perspective, because MoF works based on public expectation. It is different from approach used by Indonesian Supreme Audit Institution, however, their concept with financial measurement is basically similar.

Balanced scorecard implementation has positively improved MoF performance accountability, it is proven by the result of performance accountability evaluation, conducted Ministry for State Apparatus Reform. in 2016, MoF achieved " $A$ " (satisfying) with earned the highest score $(83,79)$ among 77 ministries and public agencies. Furthermore, both in 2017 and 2018, MoF earned the highest indicator score in performance planning component, which were 25,46 and 26,20 , respectively, this is because balanced scorecard highlights on strategic planning Not only raising performance accountability, balanced scorecard also has contributed to the improvement of bureaucratic reform index in MoF.

Although this papers includes the significant factors in improving the outcome of balanced scorecard implementation, however there are two limitations regarding this study that can be researched in future, first, this study only use data in MoF and few data from SAI, and second, the different impact toward the quality of performance accountability between government organizations that applied balance scorecard and those which do not applied it, has not been covered by this paper.

\section{References}

Awadallah, E.A. \& Allam, A. (2015). A Critique of the Balanced Scorecard as a Performance Measurement Tool. International Journal of Business and Social Science, 6 (7) , 91-99.

Budiarso, A. (2014). Improving Government Performance in Indonesia: The Experience of The Balanced Scorecard in The Ministry of Finance. Retrieved from http ://www.canberra.edu.au/researchrepository/file/1a2 c8cf2 - bdca- 47bd - 86d5674f3a216b70/1/full_text.pdf on 2 August 2019.

da Cruz, N.F. \& Marques, R.C. (2014). Scorecards for Sustainable Local Governments. Cities, (39) pp. 165-170.

Indonesian Minister of Finance. (2014). Minister of Finance decree no 467 of 2014 on Performance Management in Ministry of Finance. Retrieved from https://www.kemenkeu.go.id/media/5316/kmk-467tahun-2014.pdf on 16 August 2019.

Indonesian Ministry of Finance. (2015). Dialog Berbasis FACT. Buletin Kinerja, XXVI, 3-4. Retrieved from https ://www.kemenkeu.go.id/media/5026/buletinkinerja-xxvi-2015.pdf on 15 August 2019. 
Indonesian Ministry of Finance. (2019a). Strategy Map of $2019 . \quad$ Retrieved from https://www.kemenkeu.go.id/profil/pengelolaankinerja-dan-risiko/peta-strategi/ on 15 August 2019. Indonesian Ministry of Finance. (2019b). Presentation Material for Entry Meeting : Evaluation of Performance Accountability, Bureaucratic Reform and Integrity Zone in Ministry of Finance.

Indonesian Ministry of State Apparatus and Bureaucratic Reform. (2014a). Minister for State Apparatus Reform Decree no 14 of 2014 on Evaluation Guidelines on Bureaucratic Reform in Government Agencies. Retrieved from https://jdih.menpan.go.id/data_puu/Permenpan $\% 20$ No\%2014\%20tahun\%202014\%20(Lengkap).pdf on 16 August 2019.

Indonesian Ministry of State Apparatus and Bureaucratic Reform. (2014b). Minister for State Apparatus Reform Decree no 53 of 2014 on Technical Guidelines on Performance Agreement, Performance Reporting And Review Of The Performance Report Government Agencies. Retrieved from http://birokeuangan.ub.ac.id/wpcontent/uploads/2014/01/PERMENPAN-NO.-532014-pemerintah.net_.pdf on 16 August 2019.

Indonesian Supreme Audit Institution. (2018). Performance Report of 2018. Retrieved from http://www.bpk.go.id/assets/files/storage/2019/07/fi le_storage_1562836555.pdf on 15 August 2019.

Kaplan, R.S. \& Norton, D.P. (1992). The Balanced Scorecard-Measures That Drive Performance. Harvard Business Review, 1(2) pp. 70-71.

Kaplan, R.S. (1999). Balanced Scorecard for PublicSector Organizations. Balanced Scorecard Report, Reprint No. B9911C.

Mcdonald, K. (2018). What is The Difference Between Customers, Users, and Stakeholders. Retrieved from https://www.kbp.media/customers-usersstakeholders/ on 15 August 2019.

Ndevu, Z.J. \& Muller, K. (2018). Operationalising Performance Management in Local Government : The Use of The Balanced Scorecard. SA Journal of Human Resource Management, 1(2).

Pasaribu, A., Andika, M., Dwi, G, Rachmanda, R., \& Wibisono, D. (2016). A Review of Performance Management Using The Balanced Scorecard in Public Sector. Asia Pacific Journal of Advanced Business and Social Studies, 2 (2) pp. 1-2.

Quesado, P., Guzmán, B.A., \& Rodrigues, L.L. (2018). Advantages and Contributions in The Balanced Scorecard Implementation. Intangible Capital, 14 (1), pp. 186-20. 